\title{
EKSTRAPOLASI DATA HUJAN MENGGUNAKAN JARINGAN SYARAF TIRUAN BACK PROPAGATION
}

\section{The Extrapolation of Rainfall data by Neural Network Backpropagation}

\author{
Rr. Rintis Hadiani \\ Program Studi Teknik Sipil Fakultas Teknik Universitas Sebelas Maret \\ Jl. Ir. Sutami 36 A Solo 57126 \\ e-mail: rintish@gmail.com
}

\begin{abstract}
Hydrological analysis need 10 years of rainfall data (of 20 years suggested). If it's less than ten years, then it's extrapolated based on the historical data. This is in order to qualify the analysis. The characteristic of rainfall data is stationer, have no trend, and has a seasonal pattern. Neural Network is the method that can adopt the characteristic of rainfall data. The object of the research is rainfall data that located in Kaliasem watershed, Lumajang, Indonesia. The step is modelled by ANN, verify the model, and then implementing the model on the other watershed. The rainfall data station was selected that closed with Kaliasem watershed i.e. Kedung sangku station, Senduro station, and Ranupakis station. Modelling ANN based on Kedungsangku data, and verify with Senduro data, and then implemented in Ranupakis data. The result shows that the reliability of model $80 \%$ on Confidence Interval 95\%. The ANN on this research have two hidden layers with two neurons in one layer. The model has implemented in Bengawan Solo watershed (Wonogiri district), the result shows that the reliability $58 \%$ to $79 \%$ ).
\end{abstract}

Keywords: Back Propagation, Kaliasem Catchment Area, Extrapolation, Neural Network

\begin{abstract}
Abstrak
Dalam suatu analisis hidrologi, dibutuhkan paling sedikit 10 tahun data hujan Jika data kurang dari 10 tahun maka dilakukan ekstrapolasi data hujan. Hal ini dilakukan agar jumlah data memenuhi syarat analisis. Karakteristik data hujan merupakan deret data yang stasioner, tidak mempunyai trend, dan mempunyai pola musiman. Salah satu metode yang sesuai dengan karakter tersebut adalah Jaringan Syaraf Tiruan dengan Back Propagation (JSTBP). Metode ini sesuai dengan data hujan yang bersifat stochastik. Objek Penelitian adalah stasiun hujan yang terletak di DAS Kaliasem, Kab. Lumajang. Langkah yang dilakukan adalah pemodelan dengan JST, kemudian verifikasi model. Selanjutnya dilakukan implementasi model. Stasiun hujan yang dipilih adalah yang berpengaruh pada DAS Kaliasem. Dipilih 3 stasiun hujan, yaitu sta. Kedungsangku dan sta. Senduro, Sta. Ranupakis. Sta. Kedungsangku digunakan sebagai pembangun model ekstrapolasi. Sta. Senduro sebagai data verifikasi. Dan implementasi pada stasiun Ranupakis. Hasil penelitian ini diterapkan pada sub DAS Bengawan Solo, di Kab. Wonogiri. Hasilnya menunjukkan bahwa metode ini mempunyai keandalanan $58 \%$ sampai 79\% (Shakti, D.W., 2014; Ginting, J.E. dkk, 2014; Prasetyo,H.E. dkk, 2014; Shakti, D.W. dkk, 2014). Hasil penelitian ini menunjukkan bahwa keandalan mencapai $80 \%$ pada Confidence Interval $(C I)=95 \%$ (berdasarkan parameter model yang sesuai). Hasil akhir menunjukkan bahwa JSTBP mempunyai parameter 2 layer tersembunyi dengan 2 neuron.
\end{abstract}

Kata kunci: Back Propagation, DAS Kaliasem, Ekstrapolasi Data, Jaringan Syaraf Tiruan

\section{PENDAHULUAN}

Setiap perencanaan infrastruktur keairan, memerlukan perencanaan hidrologi. Perencanaan hidrologi memerlukan deret data historis dalam kurun waktu minimal 10 tahun (SNI 1724-2015). Hasil analisis makin akurat jika deret data lebih panjang, sampai 20 tahun (SNI 2415-1991). Salah satu parameter dalam perencanaan hidrologi adalah data hujan. Permasalahannya adalah masih banyak stasiun hujan (yang menjadi acuan dalam analisis) mempunyai deret data 
kurang dari 10 tahun (hasil survei lapangan). Dalam memenuhi persyaratan analisis, maka kekurangan data tersebut diekstrapolasi.

Ekstrapolasi merupakan metode forecasting untuk data yang mempunyai sifat stochastik dan tidak punya trend. Sedangkan deret data hujan bersifat stochastik dan tidak mempunyai trend. Berdasarkan hal tersebut, maka salah satu metode yang sesuai dengan karakter data tersebut adalah metode Jaringan Syaraf Tiruan (JST) berdasarkan Back Propagation (JSTBP).

Pada saat ini, khususnya stasiun hujan di luar P. Jawa, banyak yang mempunyai deret data hujan kurang dari 10 tahun. Jika ada yang mempunyai deret 10 tahun, beberapa diantaanya sering dijumpai datanya tidak lengkap. Maka metode JSTBP ini merupakan salah satu solusi diyakini bisa digunakan.

Metode JSTBP ini mudah diikuti, menggunakan program matlab yang mempunyai fungsi memudahkan sebagian operasi algoritmanya.

Penelitian ini berharap mendapatkan model untuk mengektrapolasi data yan kurang dari 10 tahun.

Tujuan dari penelitian ini adalah membangkitkan data pada kurun waktu tertentu (beberapa tahun ke depan terhitung dari akhir data historis) untuk memenuhi syarat analisis hidrologi berdasarkam metode JSTBP.

\section{Data hujan}

Data yang digunakan adalah data sekunder. Sebelum digunakan dalam analisis, maka data harus divalidasi. Validasi dilakukan dengan cara uji konsistensi data. Secara statistik, data harus konsisten (Soemarto, 1986; Sri Harto, 1983).

Uji konsistensi menggunakan kurva massa ganda. Kurva merupakan scaterplot dari kumulatif rerata suatu stasiun hujan terhadap kumulatif rerata stasiun hujan yang lain (yang digunakan sebagai rujukan). Caranya adalah sebagai berikut:

- Hitung hujan kumulatif tahunan di tiap stasiun hujan.

- Hitung hujan kumulatif tahunan rerata.

- Buat scaterplot hujan kumulatif tahunan di satu stasiun hujan dengan hujan kumulatif tahunan rerata.
- Bila grafik membentuk garis linear (lurus), maka deret ata disebut konsisten, dan bila sebaliknya (tidak lurus atau berbelok) disebut tidak konsisten.

Selanjutnya data dianalisis menjadi data yang memenuhi syarat input:

- Ubah data menjadi data hujan dengan periode yang dikehendaki (dalam penelitian ini 10 harian).

- Beri catatan pada data yang kosong (maka periode tersebut dianggap tidak valid, dikosongkan)

- Harus diisi data yang kosong

Mengisi data yang kosong:

- Data yang kosong diisi dengan metode statistik, yaitu rerata pada bulan yang sama selama 10 tahun data yang ada.

- Data outlier diganti dengan data maksimum yang pernah terjadi.

\section{Model Jaringan Syaraf Tiruan (JST) dengan Back Propagation (BP) untuk Hidrologi}

Secara umum JST mempunyai struktur jaringan dengan tiga atau lebih layer yang terdiri dari layer masukan, layer tersembunyi, dan layer keluaran. Masingmasing layer terdiri dari beberapa node. Pada penelitan ini dapat digambarkan struktur JST seperti Gambar 1.

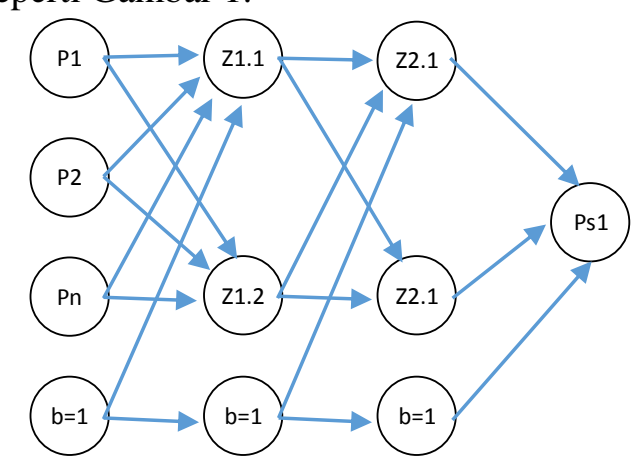

Keterangan:

$\mathrm{P} 1$ = masukan data ke 1 ,

$\mathrm{Pn}=$ masukan data ke $\mathrm{n}$,

Z1.1 = peubah bantu ke 1 pada layer tersembunyi 1 ,

$\mathrm{Z} 1.2$ = peubah bantu ke 2 pada layer tersembunyi 1 ,

$\mathrm{Z} 2.1$ = peubah bantu ke 1 pada layer tersembunyi 2 ,

$\mathrm{Z} 2.1$ = peubah bantu ke 2 pada layer tersembunyi 2 ,

$\mathrm{B}=1=$ nilai bias yang ditentukan sama dengan 1 ,

Ps1 = keluaran data ke 1 .

Gambar 1. Pemodelan data untuk ekstrapolasi

Hubungan antar peubah dinyatakan sebagai persamaan (1). 


$$
\mathrm{Ps}=\mathrm{f}(\mathrm{P} 1, \mathrm{P} 2, \ldots, \mathrm{Pn})
$$

Pada layer tersembunyi, modl hujan membentuk :

- Keluaran di unit $\mathrm{Zp.j} \quad(\mathrm{j}=1,2, \ldots, \mathrm{p})$ dihitung sebagai persamaan (2)

$$
Z p_{\text {net }_{j}}=V_{j 0}+\sum_{j=1} X_{i} V_{j i}
$$

Data hujan mempunyai sifat periodik yang khas, yaitu berulang mengikuti karakteristik iklim atau disebut mengikuti pola musiman (Suharyanto, 1999). Jumlah layer tersembunyi dan neuron ditentukan dengan cara coba-coba, dimulai dari 1 .

JST mempunyai fungsi pengaktif jaringan yang disebut fungsi aktivasi yaitu fungsi yang dipakai untuk menentukan keluaran model. Pada metode back propagation, fungsi yang dipakai mensyaratkan kontinu, terdeferensial dengan mudah, dan merupakan fungsi yang tidak turun. Fungsi yang memenuhi syarat tersebut adalah fungsi sigmoid biner yang memiliki range $f(x)$ $(0,1)$ dan sigmoid bipolar dengan range $f(x) \sim$ $(-1,1)$ (Siang, 2005). Fungsi sigmoid biner dirumuskan sebagai persamaan (Matlab 7.01, 2004) seperti persamaan (3).

$$
f(x)=\frac{1}{1+e^{-x}}
$$

dengan turunan

$$
f(x)=f(x)(1-f(x))
$$

yang dinyatakan dalam fungsi Transfer LogSigmoid dan Transfer Tan-Sigmoid.

Sedangkan fungsi Transfer sigmoid bipolar dirumuskan sebagai persamaan:

$$
f(x)=\frac{2}{1+e^{-x}}-1
$$

dengan turunan

$$
f^{\prime}(x)=\frac{(1+f(x))(1-f(x))}{2}
$$

yang dinyatakan dalam fungsi Transfer Linear.

Berdasarkan karakteristiknya, data hujan mengikuti pola aktivasi sigmoid biner.

Dalam pemodelan ini, data hujan harus terdistribusi normal dengan kisaran nol sampai satu. Bila hasil uji menunjukkan data tidak normal, maka data dinormalkan dengan skala $(0,1)$ menggunakan transformasi sesuai persamaan (7) (Siang, 2005).

$$
\mathrm{x}^{\prime}=\frac{0,8(\mathrm{x}-\mathrm{a})}{\mathrm{b}-\mathrm{a}}+0,1
$$

dengan: $\mathrm{a}=$ data minimum $; \mathrm{b}=$ data makssimum; $\mathrm{x}=$ data yang akan ditransformasikan; $\mathrm{x}^{\prime}=$ data hasil transformasi.

- Buat data sebagai runtun waktu.

- Bagi menjadi 3 bagian (dalam signifikan tahun).

- Bagian 1 sebagai input, bagian 2 sebagai target dalam pemodelan, bagian 3 sebagai aplikator untuk menentukan keandalan aplikasi.

- Model mempunyai parameter 1 layer masukan, 2 layer tersembunyi dengan 2 neuron, 1 layer keluaran.

- Model menggunakan jaringan pembelajaran Gradien descant (traingdm) dengan aktivasi logsig ke layer tersembunyi dan purelin ke layer keluaran.

- Simulasi model berhenti pada 1000 epoh atau mean square error $(M S E)=0,05$.

- Pengulangan simulasi dilakukan jika parameter statistik (mean, standar deviasi, dan median) di luar confidence interval $(C I)=95 \%$.

Syarat awal pemodelan

- Data mempunyai satuan metrik yang sama.

- Data harus terdistribusi normal, jika hasil uji menunjukkan tidak normal maka data dinormalisasi.

Pemodelan JST

- Pre analisis data untuk membentuk JST, yang digunakan adalah data bagian 1 dan data bagian 2 .

- Model JST, yang digunakan adalah data bagian 2 dan data bagian 3 .

Algoritma dengan JST untuk simulasi

- Masukkan data input (bagian 1) dan data target (bagian 2).

- Set bobot awal,

- Set parameter model JST yaitu, epoh, goal, learning rate (lr), show step (jika diperlukan),

- Pelatihan jaringan, bobot akhir terhitung, model terbentuk. 
- Masukkan Persamaan (1)-Persamaan (7) merupakan bagian dari model.

- Bakukan bobot dan aplikasikan untuk ekstrapolasi dengan masukkan data input (bagian 2)

- Periksa hubungan data hasil simulasi dengan data historis (bagian 3)

- Hitung parameter statistik mean, standar deviasi, dan median. Ketiganya harus diantara batas atas dan batas bawah pada $\mathrm{CI}=95 \%$.

- Jika di luar batas CI, maka lakukan simulasi lagi.
Hasil simulasi diuji dengan menggunakan theory of runs. Menurut teori ini, dua proses kejadian yang berurutan dan berseberangan pada suatu batasan dalam suatu kurun waktu tertentu dapat mengidentifikasi kondisi hidrologi (Yevjevich, 1972).

Ada dua macam runs yaitu run-length dan run-sum. Run-length digunakan untuk analisis prediksi waktu (analisis frekuensi). Run-sum untuk analiis durasi dan intensitas hujan. Run-length dan run-sum dapat digambarkan seperti Gambar 2 dan Gambar 3.

\section{Uji model JST}

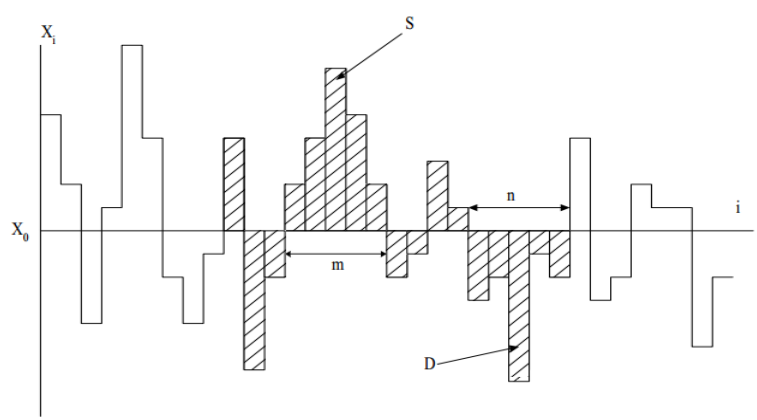

Gambar 2. Gambaran Positive Run-length, m, Positive Run-sum, S, Negative. Run-length,n, dan Negative Run-sum, D pada Deret Diskret (Yevjevich, 1972:176)

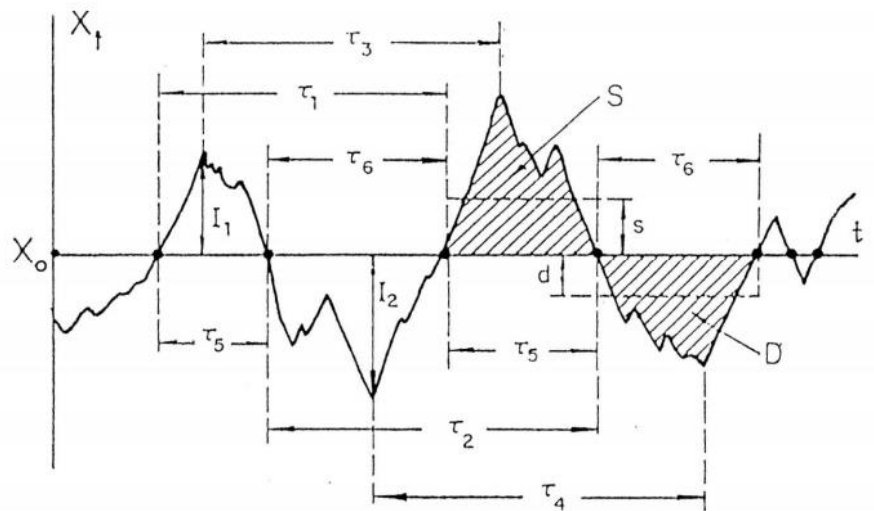

Keterangan :

run $\tau_{1}$ : jarak awal diantara dua positive run,

run $\tau_{2}$ : jarak akhir diantara dua positive run,

run $\tau_{3}$ : jarak terjadinya intensitas maksimum diantara dua periode surplus berurutan,

run $\tau_{4}$ : jarak terjadinya intensitas maksimum diantara dua periode defisit berurutan,

run $\tau_{5}$ : positive run-length (panjang durasi surplus), kadang disebut time-on untuk runtun waktu yang menerus (continuous),

run $\tau_{6}$ : negative run-length (panjang durasi defisit), kadang disebut time-off untuk runtun waktu yang menerus, run $\mathrm{S}$ disebut positive run-sum (komulatif dalam kurun surplus), dengan waktu $\mathrm{m}$,

run $\mathrm{D}$ disebut negative run-sum (komulatif dalam kurun defisit), dengan waktu n, runs I1 dan I2 disebut runintensities (intensitas maksimum),

runs $\mathrm{S}$ dan $\mathrm{D}$ disebut average positive and negative run-intensities sebagai dua parameter acak, run-sum dan runlength,

Jumlah $m+n=r$, disebut sebagai pasangan run-length, $r$, sr merupakan rerata intensitas pada durasi surplus, $d$ merupakan rerata intensitas pada durasi defisit intensitas,

$\mathrm{X}_{0}$ : ambang batas untuk menentukan kondisi defisit atau surplus yang berupa rerata data (mean) atau nilai tertentu (seperti median atau nilai lain yang dikehendaki)

Gambar 3. Definisi Runs (Yevjevich, 1972:175) 
Hubungan variabel run dinyatakan dalam persamaan (8)- persamaan (10).

$$
\begin{aligned}
& E\left(r_{q}\right)=\frac{1}{q(1-p)}=\frac{1}{p q} \\
& p=\frac{m}{m+n} \\
& q=\frac{n}{m+n}
\end{aligned}
$$

dengan syarat batas $0<\mathrm{q}<1$.

dengan: $m=$ positive run-length; $\mathrm{n}=$ negative run-length $; \mathrm{r}=\mathrm{m}+\mathrm{n} ; \mathrm{E}(\mathrm{r})=$ nilai taksiran $\mathrm{r}$; q=probabilitas posotive runlength; $\mathrm{p}=$ probabilitas negative runlength.

Rerata total run-length, $r_{q}$, dalam suatu deret $\mathrm{N}$ dinyatakan dalam persamaan (11)

$$
\bar{r}_{q}=\frac{1}{k_{r}} \sum_{j=1}^{k_{r}} r_{q, j}
$$

Hasil simulasi (keluaran model) harus ada dalam batas toleransi atas dan toleransi bawah yang mengikuti persamaan (12) sampai persamaan (14).

Batas Bawah $\leq \overline{r_{q}} \leq$ Batas Atas

Batas Bawah mengikuti persamaan (13).

$\frac{1}{p q}-\frac{t_{\alpha / 2}}{p q}\left(\frac{p^{3}+q^{3}}{k_{r}}\right)^{1 / 2}$

sedangkan Batas atas mengikuti persamaan (14).

$$
\frac{1}{p q}+\frac{t_{\alpha / 2}}{p q}\left(\frac{p^{3}+q^{3}}{k_{r}}\right)^{1 / 2}
$$

\section{Analisis run berdasarkan theory of run}

Dalam analisis run, deret data harus memenuhi syarat run yang mengikuti langkah sebagai berikut:

- Tentukan batas ambang $X_{0}$ (dalam hal ini $\mathrm{X}_{0}=$ tinggi hujan pada probabilitas 50 , yaitu pada $c d f=0,5$ )

- Hitung durasi defisit pada tiap periode setiap tahun, $\mathrm{T}_{6}$.

- Hitung intenitas hujan pada tiap durasi defisit, $\mathrm{I}_{\mathrm{d}}$,

- Hitung intensitas hujan maksimum pada tiap periode defisit setiap tahun, $\mathrm{I}_{2}$,
- Hitung frekuensi defisit pada tiap tahun,

- Hitung total run sesuai persamaan Rerata total run-length $\left(r_{q}\right)$

- Uji total run sesuai batas

- Bila hasil uji di luar batas toleransi, maka ulangi lagi simulasinya.

- Jika sudah memenuhi syarat, maka tentukan hasil ekstrapolasi hujan.

\section{METODE PENELITIAN}

Secara umum metode yang digunakan adalan analisis deskriptif. Langkah penelitian ini adalah:

- Data yang digunakan adalah data sekunder.

- Uji validasi data, dengan menguji konsistensi menggunakan metode kurva massa ganda. Jika data tidak konsisten, maka diperbaiki sehingga deret data menjadi konsisten.

- Ubah data sesuai peiode yang dikehendaki, dalam hal ini 10 harian (dasarian).

- Bagi data menjadi 3 bagian, bagian pertama adalah input, bagian kedua adalah target pola simulasi, dan bagian ketiga adalah data untuk verifikasi model.

- Analisis distribusi data.

- Analisis batas ambang.

- Tentukan durasi surplus dan defisit, serta intensitas hujan surplus dan defisit berdasarkan batas ambang pada data observasi.

- Tentkan parameter JST.

- Lakukan simulasi dengan JST

- Uji nilai run, (harus dalam batas toleransi).

- Hasil simulasi akhir merupakan ekstrapolasi data.

Wilayah studi

- Studi dilakukan di DAS Kaliasem, yang diverifikasi di DAS Umbul yang merupakan sub DAS Bondoyudo.

Terletak di Lumajang Jawa Timur. Lokasi ini pada koordinat $11205^{\prime}$ 113o22'BT dan 7o52'-8o3' LS. 
- Stasiun hujan yang berpengaruh di DAS Kaliasem adalah Sta. Kedungsangku, Sta. Senduro, Sta. Ranupakis dengan runtun waktu tahun $1980-2005$.

Pemodelan dengan JST dengan algoritma, menggunakan matlab sebagai berikut:

- Data yang digunakan berupa data hujan tahun 1980-2003 (24 tahun) dari 26 tahun data tersedia.

- Data dibagi menjadi data masukan (hujan tahun 1980-1987), data target pelatihan model (tahun 1988-1995, dan simulasi model (tahun 1996-2003)

- Pre-analisis data agar masukan mempunyai range yang relatif kecil dengan skala 0-1.

- Membangun model JST hujan.

- Set bobot awal, bobot bias pada layer tersembunyi,

- Set parameter model yaitu epoh, goal, learning rate (LR), dan show step.

- Nilai bobot akhir terhitung.

- Lakukan simulasi JST, dengan masukan tahun 1996-2003 terhadap jaringan dengan bobot akhir.

- Plotting keluaran data observasi dan data simulasi tahun 1996-2003.

- Periksa median dan standar deviasi hasil simulasi dan data observasi tahun 1996-2003.

- Median dan mean hasil simulasi = observasi (atau dalam batas confidence interval yang ditentukan.

- Jika tidak sesuai, maka lakukan lagi poin (4) dengan membangun JST ulang.

- Jika sudah memenuhi syarat, maka berdasarkan bobot akhir gunakan untuk ekstrapolasi.

Langkah ekstrapolasi:

- Gunakan data untuk pemodelan (tahun 1990-2005).

- Data masukan tahun 1990-1997 (8 tahun), dan data keluaran tahun 19982005 (8 tahun) untuk verifikasi berdasarkan bobot akhir terhitung.
- Dengan model yang sama lakukan simulasi dengan masukan data tahun 1998-2005.

- Hasil simulasi adalah data prediksi tahun 2006-2013.

\section{HASIL DAN PEMBAHASAN}

Berdasarkan uji konsistensi data yang dilakukan pada 3 stasiun hujan yaitu sta. Kedungsangku, sta. Senduro, dan sta. Ranupakis menunjukkan bahwa data konsisten. Hal ini ditunjukkan dengan dengan hasil kurva massa ganda yang linear pada masing-masing stasiun.

Parameter statistik yang digunakan adalah standar deviasi, mean, dan median. Pada pemodelan JST menggunakan data tahun 1980-2005, sedangkan pada ekstrapolasi menggunakan data tahun 19902005, maka kedua kelompok data harus mempunyai mean dan median yang sama atau dalam batas $C I$ yang ditentukan. Hasil analisis statistik terhadap standar deviasi, mean, dan median kedua kelompok data tidak berbeda nyata. Hal ini dapat dilihat pada Tabel 1.

Tabel 1. Parameter Statistik 2 kelompok Data

\begin{tabular}{lcc}
\hline Parameter Statistik & $\begin{array}{c}\text { Tahun } \\
\mathbf{1 9 8 0 - 2 0 0 5}\end{array}$ & $\begin{array}{c}\text { Tahun } \\
\mathbf{1 9 9 0 - 2 0 0 5}\end{array}$ \\
\hline Mean & 66,33 & 67,86 \\
Median & 50,00 & 51,00 \\
Standar Deviasi & 63,74 & 66,16 \\
Kurtosis & 0,56 & 0,06 \\
Skewness & 0,94 & 0,83 \\
Minimum & 0,00 & 0,00 \\
Maksismum & 343,00 & 312,00 \\
\hline
\end{tabular}

Tabel 2. Parameter Statistik data hujan 1980-2005

\begin{tabular}{lcccc}
\hline $\begin{array}{c}\text { Parameter } \\
\text { Statistik }\end{array}$ & P8005 & P9005 & Qaw & Qd \\
\hline Mean & 66,33 & 67,86 & 17,17 & 22,70 \\
Median & 50,00 & 51,00 & 15,69 & 20,70 \\
St. Devition & 63,74 & 66,16 & 7,44 & 10,91 \\
Kurtosis & 0,56 & 0,06 & 8,73 & 25,77 \\
Skewness & 0,94 & 0,83 & 2,07 & 3,61 \\
Minimum & 0,00 & 0,00 & 4,26 & 0,00 \\
Maksimum & 343,00 & 312,00 & 71,22 & 130,38 \\
\hline
\end{tabular}


Nilai mean dan median pada $\mathrm{P}_{50}$ kedua kelomok data cenderung berimpit. $\mathrm{P}_{50}$ pada analisis pdf disebut sebagai hujan normal.

Analisis distribusi dilakukan untuk menentukan distribusi yang sesuai dengan data historis. Hal ini dilakukan untuk menentukan metode $p d f$ yang sesuai. Analisis $p d f$ ini untuk menentukan batas ambang dalam analisis run.
Dalam analisis, nilai P50 dalam distribusi normal adalah median. Sehingga Nilai P50 $=50$, diinterpretasikan bahwa tinggi hujan normal adalah $50 \mathrm{~mm}$.

Dengan demikian maka didapat batas ambang, P50 = $50 \mathrm{~mm}$.

Hasil analisis menunjukan bahwa data mempunyai pola yang sama, seperti Gambar 4.

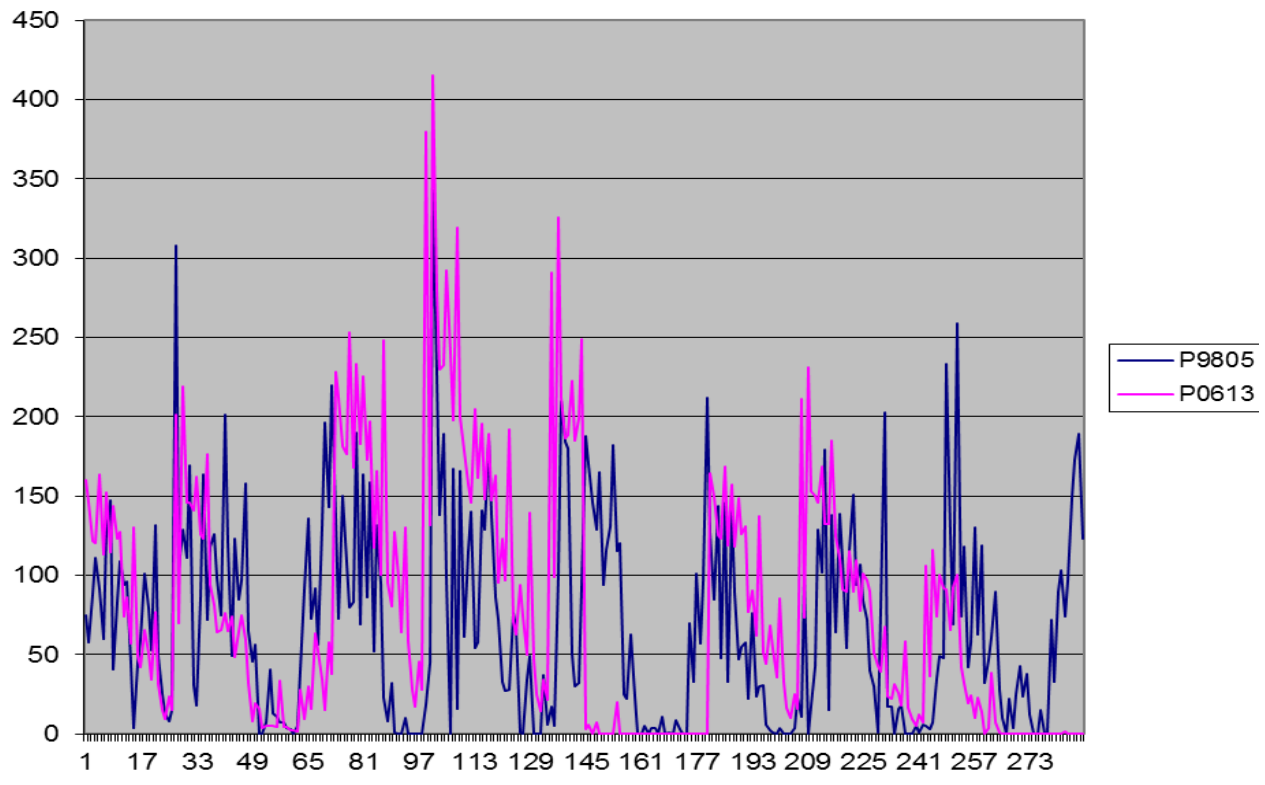

Gambar 4. Keluaran model (menggunakan mathlab) prediksi hujan tahun 2006-2013 (merah) mempunyai pola yang sama scara visual dengan model hujan historis tahun 1998-2005 (biru)

Grafik warna biru adalah data simulasi yang dilanjutkan dengan ekstrapolasi. Angka pada sumbu $\mathrm{X}$ adalah waktu yang merupakan waktu tahun 1998-2005, sedangkan hasil simulasi prediksi tahun 2006-2013.

Model ekstrapolasi data pada gambar di atas merupakan model JSTBP dengan parameter 2 layer, 2 neuron, dengan epoh 10000 , learning rate 0,8 . Dan goal 0,0001 .

Hasil analisis runs data historis menunjukkan bahwa ada 102 di atas dan 114 di bawah batas ambang, dengan P-value $=0,00$. Berdasarkan persamaan (9) dihitung bahwa $\mathrm{p}=0,47$ (bedasarkan 102/216), $\mathrm{q}=$ 0,53 (berdasarkan 114/216). Maka $\mathrm{E}(\mathrm{r})=$ 4,016 (dari $1 / \mathrm{pq}$ ). Dengan $\alpha=5 \%$, maka nilai $\mathrm{t}_{\mathrm{a} / 2}=1,96$. Dengan demikian maka berdasarkan persamaan (13) dan persamaan (14), batas atas $=4,701$ dan batas bawah $=$ 3,331 .
Analisis runs data simulasi adalah sebagai berikut:

Terdapat 99 observasi di atas dan 117 di bawah batas ambang. dengan $\mathrm{P}-$ value $=0,00$.

Perhitungan runs menunjukkan bahwa $\mathrm{p}=0,46$ dan $\mathrm{q}=0,4$. Dengan demikian maka $\mathrm{E}(\mathrm{r})=4,032$. Nilai ini ada diantara batas atas dan batas bawah data observasi. Diinterpretasikan bahwa data simulasi memenuhi syarat diterima dengan $\alpha=5 \%$ atau $C I=95 \%$. Nilai ini diinterpretasikan bahwa parameter model memiliki keandalan $95 \%$. Jika diaplikasikan ke stasiun hujan lain yang mempunyai karakter sama (tidak berbeda signifikan) maka korelasi antara data simulasi dan data historis sampai 0,8 .

Model yang sama diaplikasikan Hasil penelitian ini diterapkan pada DAS Tirtomoyo di Titik Sulingi (Danang W.S. dkk, 2014), yang merupakan anak sungai Bengawan Solo di Kabupaten Wonogiri. 
Hasil ekstrapolasi menunjukkan bahwa model dapat digunakan pada DAS lain dengan keandalan parameter sampai $95 \%$ $(\alpha=5 \%)$. Namun hasil simulasi bisa turun sampai $62 \%$.

Dengan demikian model ekstrapolasi data JSTBP adalah model dengan parameter yang baik dan terpercaya dengan CI 95\%. Tetapi jika diaplikasikan ke DAS lain, atau stasiun hujan yang mempunyai karakter berbeda, maka keandalannya turun. Dengan demikian maka setiap stasiun memiliki model JSTBP sendiri, hanya saja parameter yang digunakan bisa menggunakan parameter pada penelitian ini.

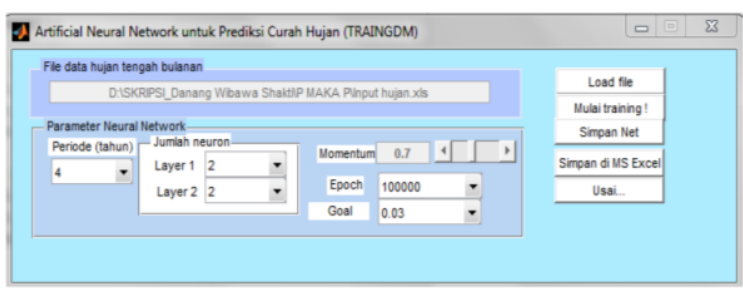

Gambar 5. Tampilan parameter JST yang merupakan masukan awal (Danang dkk, 2014) berupa layer, epoh, goal

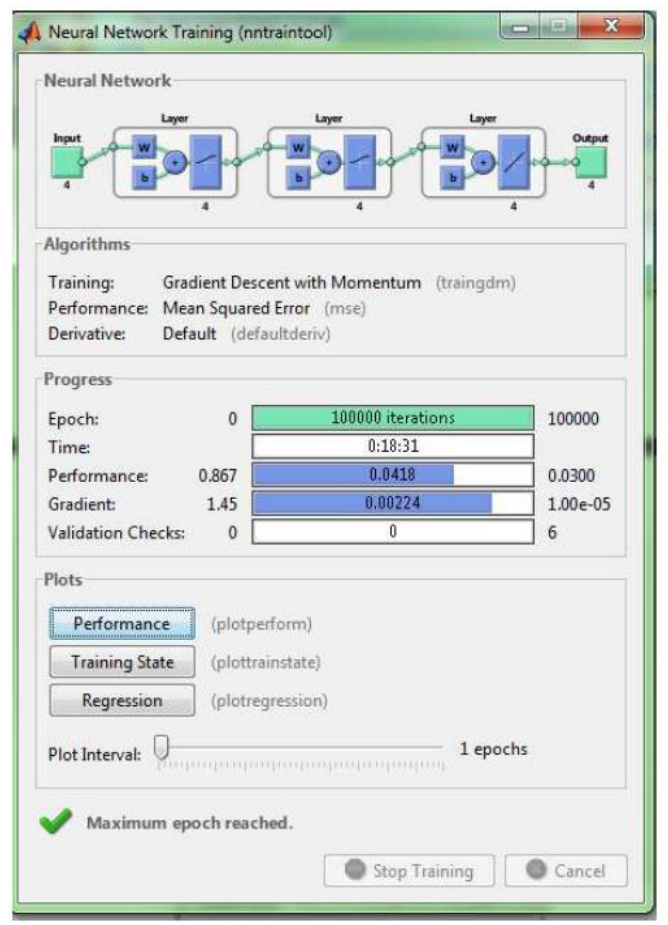

Gambar 6. Parameter traigdm dan mse, merupakan fungsi yang menjadi syarat batas model (Danang W.S. dkk, 2014; Ginting, J dkk, 2014)
Hasil pemodelannya adalah:

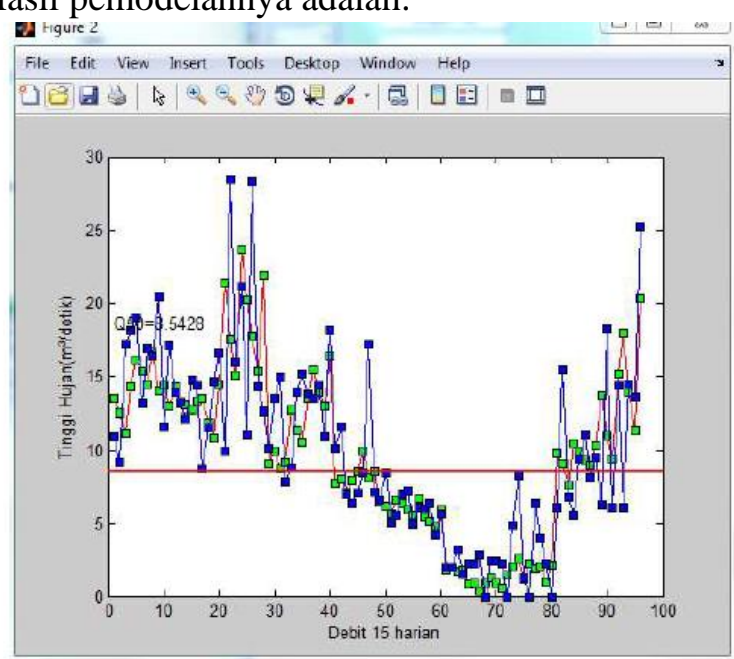

Gambar 7. Model yang digunakan di DAS Tirtomoyo di aplikasikan juga untuk simulasi debit.

Danang dkk, 2014 menggunakan ekstrapolasi data hujan untuk simulasi debit. Berdasarkan Gambar 7 menunjukkan bahwa hasil simulasi (merah) mempunyai pola yang sama dengan data historis (biru).

Hal ini menunjukkan bahwa ekstrapolasi menggunakan JST lebih mudah dilakukan asal menggunakan parameter yang tepat.

\section{KESIMPULAN DAN SARAN Kesimpulan}

Ekstrapolasi data menggunakan Jaringan Syaraf Tiruan Back Propagation (JSTBP) menunjukkan bahwa model diterima dengan $\alpha=5 \%$ atau tingkat kepercayaan $95 \%$. Jika diaplikasikan ke stasiun lain mempunyai keandalan sampai $80 \%$ pada DAS yang sama. Namun jika diaplikasikan pada DAS lain keandalan berkisar 58\%-79\%.

Parameter model terpilih terdiri dari 1 layer masukan, 2 layer tersembunyi dengan 2 neuron, 1 layer keluaran. Jumlah masukan = jumlah keluaran $=8$ (tahun). Model JSTBP menggunakan aktivasi logsig, logsig, purelin, traingdm.

\section{Saran}

Jika menggunakan model ini, maka sebaiknya membangun kembali JST nya (parameter yang sama) dengan koefisien 
yang sesuai karakter data masukan atau data baru.

\section{DAFTAR PUSTAKA}

29381_SNI 1724-2015-Analisis hidrologi, hidraulik, dan kriteria desain bangunan di sungai.

Danang Wibawa Shakti, Rintis Hadiani, Setiono, 2014. Analisis Debit beerdasarkan Hujan Kumulatif 15 Harian dengan Metode Jaringan Syaraf Tiruan Back Propagation pada DAS Tirtomoyo untuk Titik Sulingi. Matriks Teknik Sipil, Vol 2, No. 4, Desember 2014. Jurnal online. eISSN 23548630.

Jonas Eratika Ginting, Rintis Hadiani, Setiono, 2014. Prediksi Potensi Debit berdasarkan Data Hujan Maksimum Bulanan dengan Metode Jaringan Syaraf Tiruan Back Propagation di DAS Alang. Matriks Teknik Sipil, Vol 2, No. 1, Maret 2014. Jurnal online. eISSN 2354-8630

Rr. Rintis Hadiani, 2009. Analisis Kekeringan berdasarkan Data Hidrologi. Disertasi. Malang.

Sri Harto, 1993. Analisis Hidrologi, PT Gramedia Pustaka Utama, Jakarta.

Suharyanto. 1997, "Aplikasi Artificial Neural Network di Bidang Keairan", Disampaikan pada Seminar dan Pameran Teknologi Komputer, 22-23 September 1997. Diselenggarakan oleh KSAKS, Senat Mahasiswa Fakultas Teknik, UNDIP.

Sumarto, C.D. 1987, Hidrologi Teknik. Usaha Nasional, Surabaya.

Yevjevich, V. 1972. Stochastic Processes in Hydrology. Water Resources Publications, Fort Collins, Colorado, USA. 